\title{
Prospective Primary Teachers' Mathematics Anxiety-Apprehension and Its Causes
}

\author{
Emine Özdemir ${ }^{1} \&$ Burcu Sezginsoy Şeker ${ }^{2}$ \\ ${ }^{1}$ Department of Mathematics Education, Faculty of Necatibey Education, Balıkesir University, Balıkesir, Turkey \\ ${ }^{2}$ Department of Elementary Teacher Education, Faculty of Necatibey Education, Balıkesir University, Balıkesir, \\ Turkey \\ Correspondence: Emine Özdemir, Department of Mathematics Education, Faculty of Necatibey Education, \\ Balıkesir University, Balıkesir, Turkey. Tel: 90-266-241-276-2180. E-mail: eozdemir@balikesir.edu.tr
}

Received: May 18, 2017

doi:10.5539/ies.v10n11p1
Accepted: June 23, $2017 \quad$ Online Published: October 28, 2017

URL: https://doi.org/10.5539/ies.v10n11p1

\begin{abstract}
The study aims to investigate the mathematics anxiety-apprehension of prospective primary school teachers and its causes. The mathematics anxiety-apprehension of the prospective primary school teachers was analyzed using a number of variables. The prospective teachers were asked to provide written answers to open-ended questions about the causes of their mathematics anxiety. The study used mixed method research design. The quantitative data for the prospective teachers' mathematics anxiety-apprehension were collected using the Mathematics Anxiety-Apprehension Scale developed by Ikegulu (1998) and translated into Turkish with validity-reliability analyses by Özdemir and Gür (2011). The qualitative part of the study used the phenomenological method, and the prospective teachers' metaphors for aspects of mathematics were collected as data. The participants in the study were third- and fourth-grade prospective teachers studying in the Primary Education Department of the Necatibey Faculty of Education at Balıkesir University. They were chosen by simple random sampling. The independent samples t-test was computed to analyze the quantitative data, and descriptive statistics were used for the qualitative data. The study found that the mathematics anxiety-apprehension of prospective primary school teachers who were Anatolian high school graduates was significantly lower. Mathematics anxiety-apprehension did not vary by gender, and the third-grade prospective teachers had significantly higher mathematics anxiety-apprehension. The causes of the prospective primary school teachers' mathematics anxiety-apprehension were found to be related to teachers, prospective teachers, the examination system, mathematics program-related and school facilities-related causes. The prospective primary school teachers often used metaphors such as life, crossword puzzle, game and human for each sub-theme, and 166 metaphors for mathematics were identified. The themes with the highest number of metaphors were basic principles of mathematics teaching, basic mathematical skills and mathematical knowledge, respectively.
\end{abstract}

Keywords: prospective primary teacher, mathematics anxiety-apprehension, mathematics learning and teaching, metaphor, causes of mathematics anxiety-apprehension

\section{Introduction}

Mathematics anxiety is defined as "panic, desperation and cognitive disorganization that occurs in some people when they have to solve a mathematical problem" (Alkan, 2010). According to Fennema and Sherman (1976), mathematics anxiety is a strong feeling of apprehension and fear experienced when dealing with a mathematical problem. Mathematics anxiety has been described as a serious and insolvable problem that occurs when students are beginning their educational lives (Hannula, 2005). The students under the influence of such an anxiety are not able to attain the expected level of mathematical knowledge, and they may resort to the memorization of mathematical knowledge without understanding and internalizing it (Işıı, Çiltaş, \& Bekdemir, 2008). Students' mathematics anxiety inevitably causes the quality of their education to fall below the desired level. Mathematics anxiety is a psychological state that can result in failure, loss of self-confidence and inability to use abilities and skills effectively. It affects individuals' future plans and is among the important issues that educators should seriously consider (Üldaş, 2005).

Scholars have summed up the causes of mathematics anxiety in three main categories: student-related, teacher-related and education-related (A. Harris \& J. Harris, 1987). Its causes have been characterized as 
situational, dispositional and personal (Byrd, 1982). Keçeci (2011) describes the causes of mathematics anxiety as: "causes arising from the field," "causes arising from the structure of education and from educators" and "causes arising from students and their environment." Causes arising from the field include the structure and sequence of the educational program used for mathematics and factors related to the content of mathematics such as mathematical terms and formulas (Byrd, 1982; Skiba, 1990; Tobias, 1978). Causes arising from the structure of education and from educators are related to mathematics teachers' influences on students (Lazarus, 1974). It has been claimed that a considerable amount of primary and secondary level mathematics teachers have mathematics anxiety themselves and transmit it consciously or unconsciously to their students (Baydar \& Bulut, 2002; Berebitsky, 1985; Buhlman \& Young, 1982; Chaffee, 1986; Hackett, 1985; Kelly \& Tomhave, 1985).

It has been acknowledged that as well as the anxiety levels of mathematics teachers, negative teacher behaviors (Shodahl \& Diers, 1984) such as intolerant instructional methods (Fitzgerald, 1997; A. Harris \& J. Harris, 1987; Skemp, 1971) are among the factors that cause mathematics anxiety. The instructional methods used in mathematics education are another main cause of mathematics anxiety (Bohuslav, 1980; Burton, 1984; Byrd, 1982; Greenwood, 1984; Strawderman, 1985; Williams, 1988). It has been established that instructional methods based on rote learning (Buhlman \& Young, 1982; Kogelman \& Warren, 1979), inauthentic methods (A. Harris \& J. Harris, 1987; Zacharias, 1976), quick solutions for mathematical problems (A. Harris \& J. Harris, 1987) and methods that include single solution strategies (Byrd, 1982; Kogelman \& Warren, 1979; Tobias, 1978) increase mathematics anxiety. The effect of individuals' psychological and emotional characteristics on mathematics anxiety can be examined as elements of their socio-psychological state. Students fear making mistakes in mathematics classes (Zakaria \& Nordin, 2008). The negative attitudes and practices of teachers are cited as factors that affect anxiety. Another teacher attitude that causes anxiety is teachers' concentration on one student or student group (Baydar \& Bulut, 2002), which can be called favoritism.

A review of the recent literature shows that in general, prospective teachers' mathematics anxiety is related to their past experiences and primary school fs. Students' mathematics anxiety causes the quality of education to fall below the desired level. Many studies' findings indicate that mathematics anxiety affects success in mathematics negatively and it as also cognitive, emotional, behavioral and physiological effects. Although mathematics anxiety has been under investigation since the 1950s, only the recent literature has studies about the elimination and prevention of this anxiety. Some research studies suggest that mathematics anxiety can be eliminated by psychological counseling and developing mathematical skills. The identification of the causes of prospective teachers' anxiety can enable their recognition of the behaviors that lead to anxiety. It is believed that, in this way, when they start their profession, prospective teachers can observe their students' behaviors with heightened awareness and prevent the creation of an atmosphere that would lead to anxiety, make efforts to reduce anxiety and improve attitudes towards mathematics into a more positive one. For this reason, the examination of prospective primary school teachers' anxiety levels and its causes is crucial for increasing the quality of education. This study's aim is to gain insights into the prospective primary school teachers' mathematics anxiety-apprehension and its causes. Here are its research questions:

1) Does the prospective primary school teachers' mathematics anxiety-apprehension significantly differ by class level, type of high school attended or gender?

2) What are the prospective primary school teachers' metaphorical perceptions related to mathematics?

3) What are the causes of the prospective primary school teachers' mathematics anxiety-apprehension?

\section{Method}

\subsection{Research Design}

The focus of the study is to investigate whether prospective primary school teachers' mathematics anxiety-apprehension differs according to a number of variables and to explore its causes. It used a mixed method research design. Since this research design yields quantitative and qualitative results that can be compared, its reliability should be high (Patton, 1990; Hammersely \& Atkinson, 1995). Brevver and Hunter (1989) state that the reliability of studies can be increased by confirming one type of data with the other. This study's validity and reliability is ensured by triangulation.

The behaviors, meanings, perceptions and experiences related to concepts can be defined through phenomenological approach (Yıldırım \& Şimşek, 2008). For this reason, phenomenological research design was used for the qualitative part of this study. The causes of prospective primary school teachers' mathematics anxiety-apprehension were investigated using semi-structured interviews and metaphors. Its quantitative part used descriptive research design because descriptive research describes facts and events as they are (Tanrı̈ğen, 
2009). The commonly used survey method was chosen as descriptive research method for examining the prospective primary school teachers' mathematics anxiety-apprehension.

\subsection{Participants' Characteristics}

The participants in the study were third-grade (50 students) and fourth-grade (58 students) prospective teachers studying in the Primary Education Department of the Necatibey Faculty of Education at Balıkesir University. They were chosen by simple random sampling. This sampling method makes it equally probable for each student to be chosen as a participant. This study contacted $78 \%$ of the third- and fourth-grade prospective primary school teachers. This percentage was $74 \%$ for the third-grade prospective teachers and $82 \%$ for the fourth-grade prospective teachers. The prospective teachers were grouped under two categories according to the high schools from which they graduated in 2013-2014 and 2014-2015. The Anatolian high school category included Anatolian high schools, foreign language intensive high schools and Anatolian teacher training high schools. Multi-program high schools, regular high schools and Turkmen schools were the other high schools category. Of the participants, 71 were in the former category, and 37 were in the latter.

\subsection{Data Collection and Analysis}

The quantitative data for the prospective teachers' mathematics anxiety-apprehension were collected using the Mathematics Anxiety-Apprehension Scale developed by Ikegulu (1998) and adapted for Turkish and validated by Özdemir \& Gür (2011). The qualitative data were collected using an open-ended questionnaire developed by the researchers. In order to explore the causes of their mathematics anxiety-apprehension, the prospective teachers were asked to provide written answers to questions such as: "Mathematics is like ...?, because...?" and "What are the causes of your mathematics anxiety-apprehension?"

The independent samples t-test, which is among the statistical methods in SPSS 21.0, was computed for the quantitative data, and the qualitative data were analyzed using descriptive statistics. The qualitative data related to the prospective teachers' metaphorical perceptions and their perspectives of the causes of mathematics anxiety-apprehension were coded thematically, and frequency and percentages were calculated. The reliability of the study was calculated by using the formula (reliability=[consensus/consensus + dissent] x 100) as suggested by Miles and Huberman (1994). In qualitative studies, inter-rater reliability scores of $90 \%$ or above are acceptable. This study's reliability for metaphorical perceptions was $95 \%$ and for the causes of mathematics anxiety-apprehension, it was $94 \%$.

\section{Results}

\subsection{Results and Interpretations for the First Research Question}

To understand whether the prospective teachers' mathematics anxiety-apprehension significantly differ according to class level, type of high school attended and gender, the independent samples t-test was computed for the quantitative data. The results of the independent samples t-test for the variables of gender, class level and type of high school attended are shown in Tables 1, 2 and 3, respectively.

Table 1. The independent samples t-test results for the prospective teachers' mathematics anxiety-apprehension by gender

\begin{tabular}{ccccccc}
\hline Gender & $\mathrm{N}$ & $\bar{x}$ & $\mathrm{Sd}$ & $\mathrm{df}$ & $\mathrm{t}$ & Sig. \\
\hline Female & 61 & 52.2787 & 16.49559 & \multirow{2}{*}{106} & -1.848 & $.067^{*}$ \\
Male & 47 & 58.2979 & 17.14378 & & & \\
\hline
\end{tabular}

$* \mathrm{p}>.05$.

There was 6.01918 points of difference in the prospective teachers' mathematics anxiety-apprehension scores in favor of the male prospective teachers. To determine the significance of this difference, the independent samples t-test was used, and it was found that there was no statistically significant difference by gender for the prospective teachers' mathematics anxiety-apprehension [t(106)=-1.848, p>.05] (Büyüköztürk, 2006). 
Table 2. The independent samples t-test results for the prospective teachers' mathematics anxiety-apprehension by class level

\begin{tabular}{ccccccc}
\hline Class level & $\mathrm{N}$ & $\bar{x}$ & $\mathrm{Sd}$ & $\mathrm{df}$ & $\mathrm{t}$ & Sig. \\
\hline 3rd grade & 50 & 62.4800 & 12.66240 & \multirow{2}{*}{106} & \multirow{2}{*}{4.721} & $.000^{*}$ \\
4th grade & 58 & 48.3621 & 17.57161 & & \\
\hline
\end{tabular}

${ }^{*} \mathrm{p}<.05$.

There was 14.11793 points of difference in the scores of the prospective teachers' mathematics anxiety-apprehension in favor of the third-grade prospective teachers. The independent samples t-test determined that this difference was statistically significant $[\mathrm{t}(106)=4.721, \mathrm{p}<.05]$. The scores for the prospective teachers' mathematics anxiety-apprehension significantly differed by class level (Büyüköztürk, 2006), and the third-grade prospective teachers had higher levels of mathematics anxiety-apprehension.

Table 3. The independent samples t-test results for the prospective teachers' mathematics anxiety-apprehension by type of high school attended

\begin{tabular}{ccccccc}
\hline Type of high school attended & $\mathrm{N}$ & $\bar{x}$ & $\mathrm{Sd}$ & $\mathrm{df}$ & $\mathrm{t}$ & $\mathrm{Sig}$. \\
\hline Anatolian high schools & 71 & 52.1831 & 17.47759 & \multirow{2}{*}{106} & -2.352 & $.021 *$ \\
\hline Non-Anatolian high schools & 37 & 60.1081 & 14.81138 & & \\
\hline
\end{tabular}

$* \mathrm{p}<.05$.

There was 7.92501 points of difference in the scores of participant prospective teachers' mathematics anxiety-apprehension in favor of the prospective teachers who graduated from non-Anatolian high schools. The independent samples t-test found that there was statistically significant in the scores of the prospective teachers' mathematics anxiety-apprehension [ $\mathrm{t}(106)=-2,352, \mathrm{p}<.05]$. The scores for the prospective teachers' mathematics anxiety-apprehension significantly differed by type of high school attended (Büyüköztürk, 2006). The results indicated that the prospective teachers who graduated from non-Anatolian high schools had higher level of mathematics anxiety-apprehension.

\subsection{Results and Interpretations for the Second Research Question}

The metaphorical perceptions of the prospective teachers were analyzed using descriptive statistics and thematic coding. A total of 166 metaphors were provided by the prospective teachers. These metaphors were examined based on the literature and with experts in the field. The metaphors were grouped in three main themes according to their common traits. During the specification of the themes, the basic principles of mathematics teaching and the basic skills in the mathematics education program suggested by Altun (2005, pp. 8-13) were taken into account. The prospective teachers' metaphorical perceptions related to mathematics and their frequencies by class level are shown in Table 4. Table 4 shows that the theme, the basic principles of mathematics teaching, includes sub-themes such as developing positive attitudes towards mathematics, developing negative attitudes towards mathematics, establishing conceptual bases and attributing importance to prerequisite relations. The theme of mathematics knowledge includes the scope of mathematics and part-whole relations sub-themes, and the basic mathematical skills theme includes the reasoning, associating with daily life and problem solving sub-themes.

Table 4. The mathematics-related metaphorical perceptions of prospective primary teachers

\begin{tabular}{ccccc}
\hline Theme & Sub-theme & $\begin{array}{c}\text { 4th grade prospective } \\
\text { teachers' metaphors }\end{array}$ & Frequency & $\begin{array}{c}\text { 3rd grade prospective } \\
\text { teachers' metaphors }\end{array}$ \\
\hline \\
$\begin{array}{c}\text { The basic principles of } \\
\text { mathematics teaching }\end{array}$ & $\begin{array}{c}\text { Developing positive attitudes } \\
\text { towards mathematics }\end{array}$ & Crossword puzzle & 8 & Affection \\
\hline
\end{tabular}




\begin{tabular}{|c|c|c|c|c|}
\hline & Stairs & 1 & Flower & 1 \\
\hline & Child & 1 & Child & 1 \\
\hline & A deep ocean & 1 & Crossword puzzle & 1 \\
\hline & Dog & 1 & Game & 2 \\
\hline & Undiscovered island & 1 & Rose & 1 \\
\hline & Stuffed grape leaves & 1 & Love & 1 \\
\hline & A hard racetrack & 1 & Amusement park & 1 \\
\hline & Life & 1 & Balance scale & 1 \\
\hline Subtotal & & 20 & & 12 \\
\hline & Crossword puzzle & 2 & Leek & 1 \\
\hline & Sword & 1 & Meal that is hard to cook & 1 \\
\hline & People I don't like & 5 & Life & 2 \\
\hline & Mountain & 1 & A tough competition & 1 \\
\hline & Suffering & 1 & Tv series & 1 \\
\hline & Sudoku & 1 & Rose & 1 \\
\hline \multirow{9}{*}{$\begin{array}{l}\text { Developing negative } \\
\text { attitudes towards } \\
\text { mathematics }\end{array}$} & Cat & 2 & Pyramids & 1 \\
\hline & $\begin{array}{l}\text { Something that makes me } \\
\text { lose marbles }\end{array}$ & 1 & Cat & 1 \\
\hline & Machine & 1 & & \\
\hline & Mountaintop & 1 & & \\
\hline & Driving & 1 & & \\
\hline & Nothing & 1 & & \\
\hline & Trouble & 1 & & \\
\hline & Black hole & 1 & & \\
\hline & Knot & 1 & & \\
\hline Subtotal & & 21 & & 9 \\
\hline & Stairs & 1 & Stairs & 1 \\
\hline \multirow{6}{*}{$\begin{array}{c}\text { Attributing importance to the } \\
\text { prerequisite relations }\end{array}$} & Cat & 1 & Building & 1 \\
\hline & Sudoku & 1 & & \\
\hline & Human & 1 & & \\
\hline & Mountain & 1 & & \\
\hline & Construction & 1 & & \\
\hline & Trouble & 1 & & \\
\hline & Black hole & 1 & & \\
\hline
\end{tabular}




\begin{tabular}{|c|c|c|c|c|c|}
\hline & & Driving & 1 & & \\
\hline & & Crossword puzzle & 1 & & \\
\hline & Subtotal & & 10 & & 2 \\
\hline & & Foreign language & 1 & & \\
\hline & $\begin{array}{c}\text { Establishing conceptual } \\
\text { bases }\end{array}$ & Soil & 1 & Universal language & 1 \\
\hline & & Water & 1 & & \\
\hline \multicolumn{3}{|c|}{ Subtotal } & 3 & & 1 \\
\hline \multirow{20}{*}{ Mathematical knowledge } & \multirow{13}{*}{ The scope of mathematics } & Friend & 1 & Space & 1 \\
\hline & & Undiscovered island & 1 & World & 2 \\
\hline & & Knot & 1 & Matryoshka doll & 1 \\
\hline & & Life & 2 & Closed box & 1 \\
\hline & & Game & 1 & Rubik's Cube & 1 \\
\hline & & Crossword puzzle & 1 & Balance scale & 1 \\
\hline & & Internet & 1 & Deserted island & 1 \\
\hline & & A hard racetrack & 1 & Life & 1 \\
\hline & & $\begin{array}{l}\text { Everything that seems } \\
\text { easy but is hard }\end{array}$ & 1 & & \\
\hline & & Poem & 2 & & \\
\hline & & A deep ocean & 1 & & \\
\hline & & Dance of numbers & 1 & & \\
\hline & & Machine & 1 & & \\
\hline & Subtotal & & 15 & & 9 \\
\hline & & & & Puzzle & 1 \\
\hline & & & & Dominoes & 1 \\
\hline & Part-whole relation & Sudoku & 1 & & \\
\hline & & & & Maze & 1 \\
\hline & & & & Crossword puzzle & 1 \\
\hline & Subtotal & & 1 & & 4 \\
\hline \multirow{8}{*}{ Basic mathematical skills } & \multirow{7}{*}{ Reasoning } & Life & 2 & Crossword puzzle & 1 \\
\hline & & Crossword puzzle & 1 & Jumping rope & 1 \\
\hline & & \multirow{5}{*}{ Water } & & Flower & 1 \\
\hline & & & & & \\
\hline & & & & Life & 1 \\
\hline & & & 1 & Closed box & 1 \\
\hline & & & & Rubik's Cube & 1 \\
\hline & Subtotal & & 4 & & 6 \\
\hline
\end{tabular}




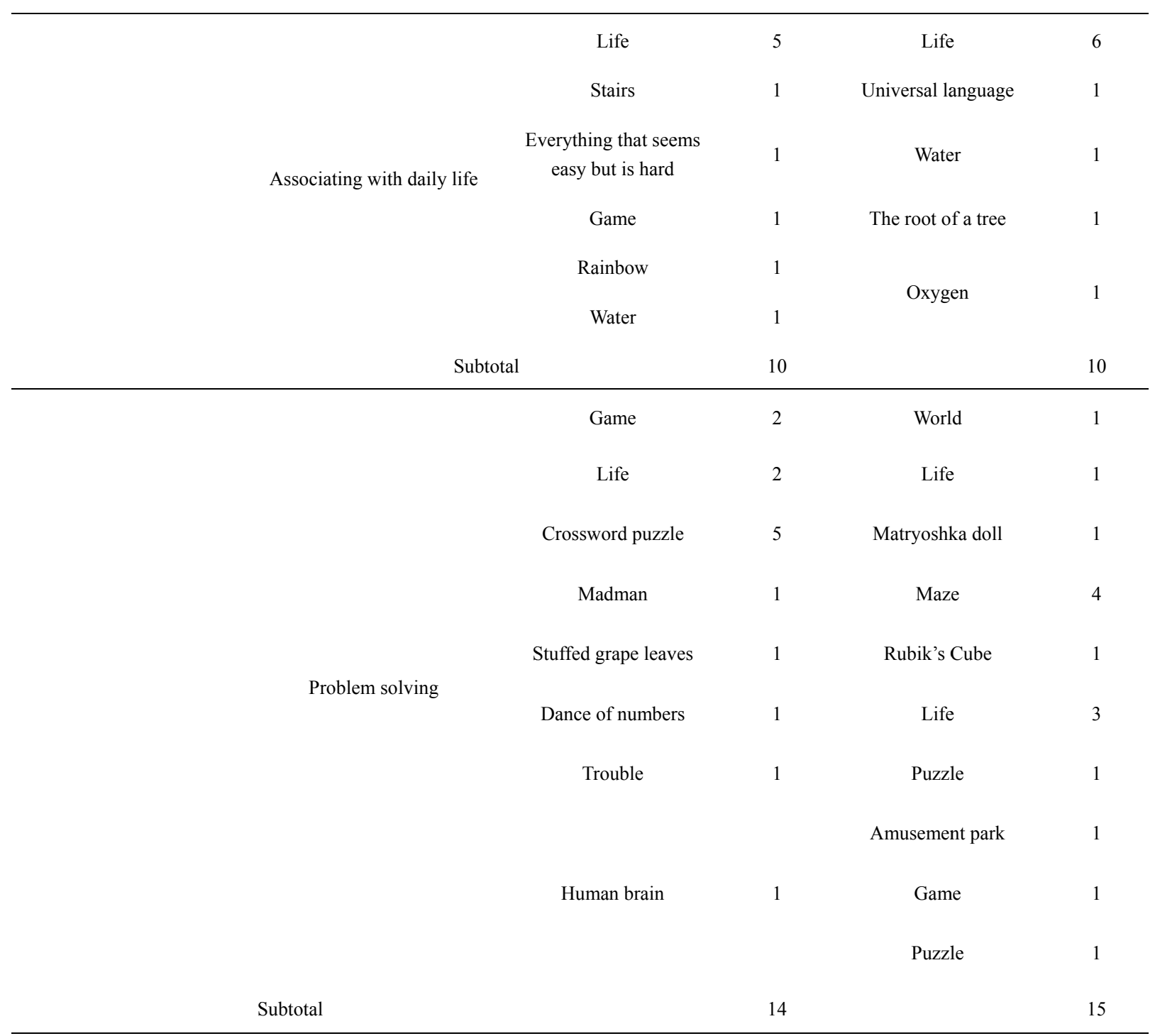

Table 4 shows that the prospective teachers frequently used the metaphor of life, crossword puzzle, game and human. However, their explanations for them differed. Sample explanations for the crossword puzzle metaphor provided by three prospective teachers are given below. The idea is that puzzles are within the scope of mathematics and develop positive attitudes towards the mathematics and problem solving sub-themes. In all examples there is same expression of "Mathematics is like .... Because ......".

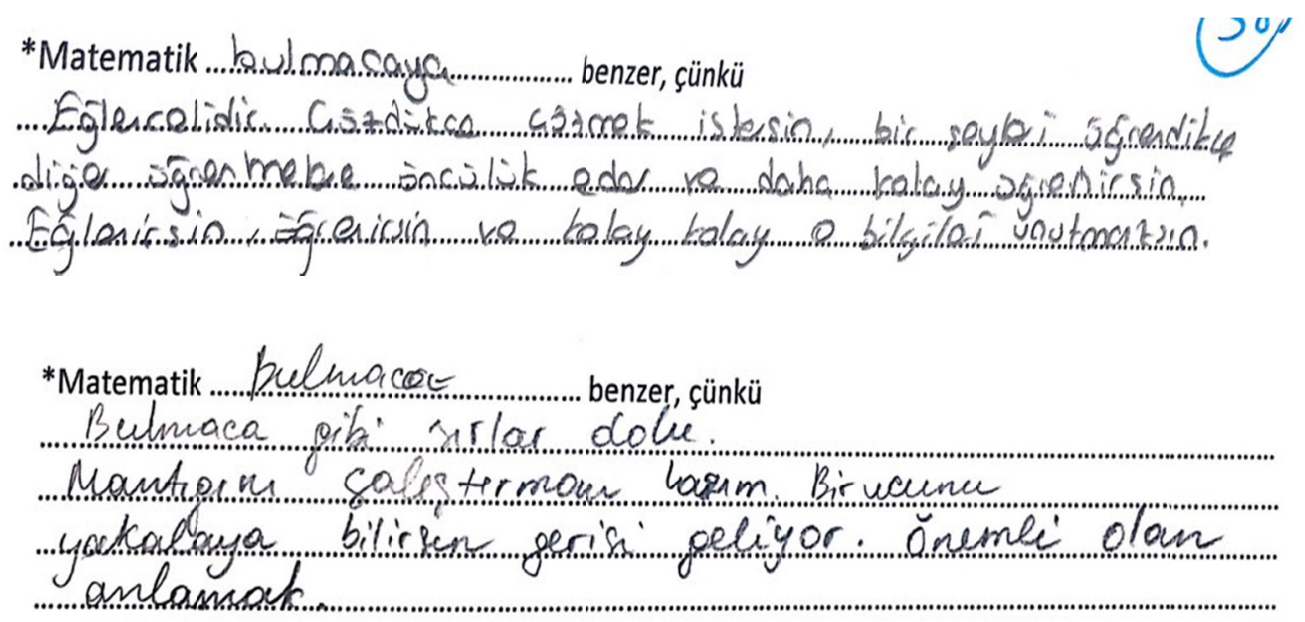




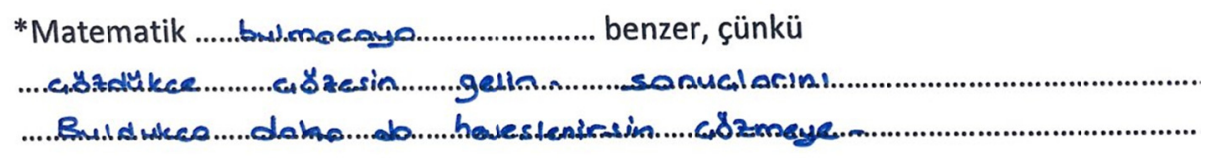

Under the developing negative attitudes towards mathematics sub-theme, the metaphor of people I don't like is used frequently. The prospective teachers who used this metaphor explained that they do not meet people they do not like, cannot get to know and understand them, and similarly they cannot make sense of mathematics. A sample explanation is provided below.

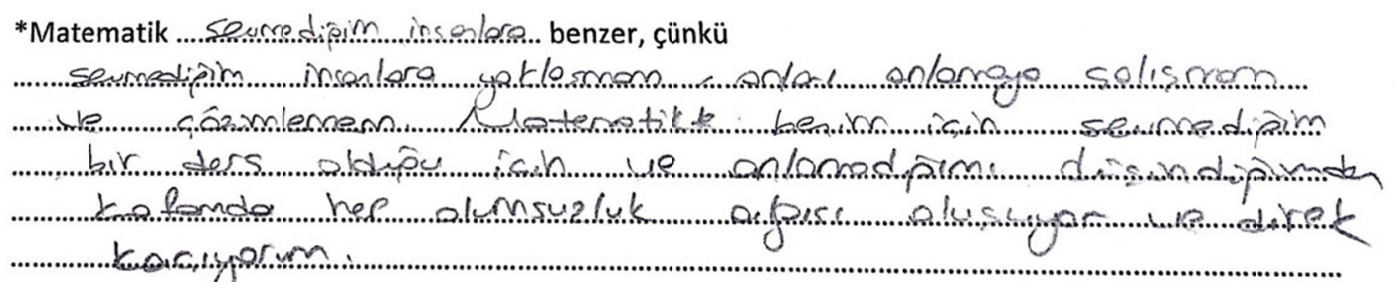

Interesting metaphors for this sub-theme included: suffering, black hole, nothing, knot, trouble, sword, something that makes me lose marbles and mountaintop. The mathematics anxiety-apprehension scores of the prospective teachers using these metaphors were found to be 70 and above, revealing that they have very high mathematics anxiety. This result indicates that the negative attitudes of the prospective teachers develop positive correlation with their high mathematics anxiety.

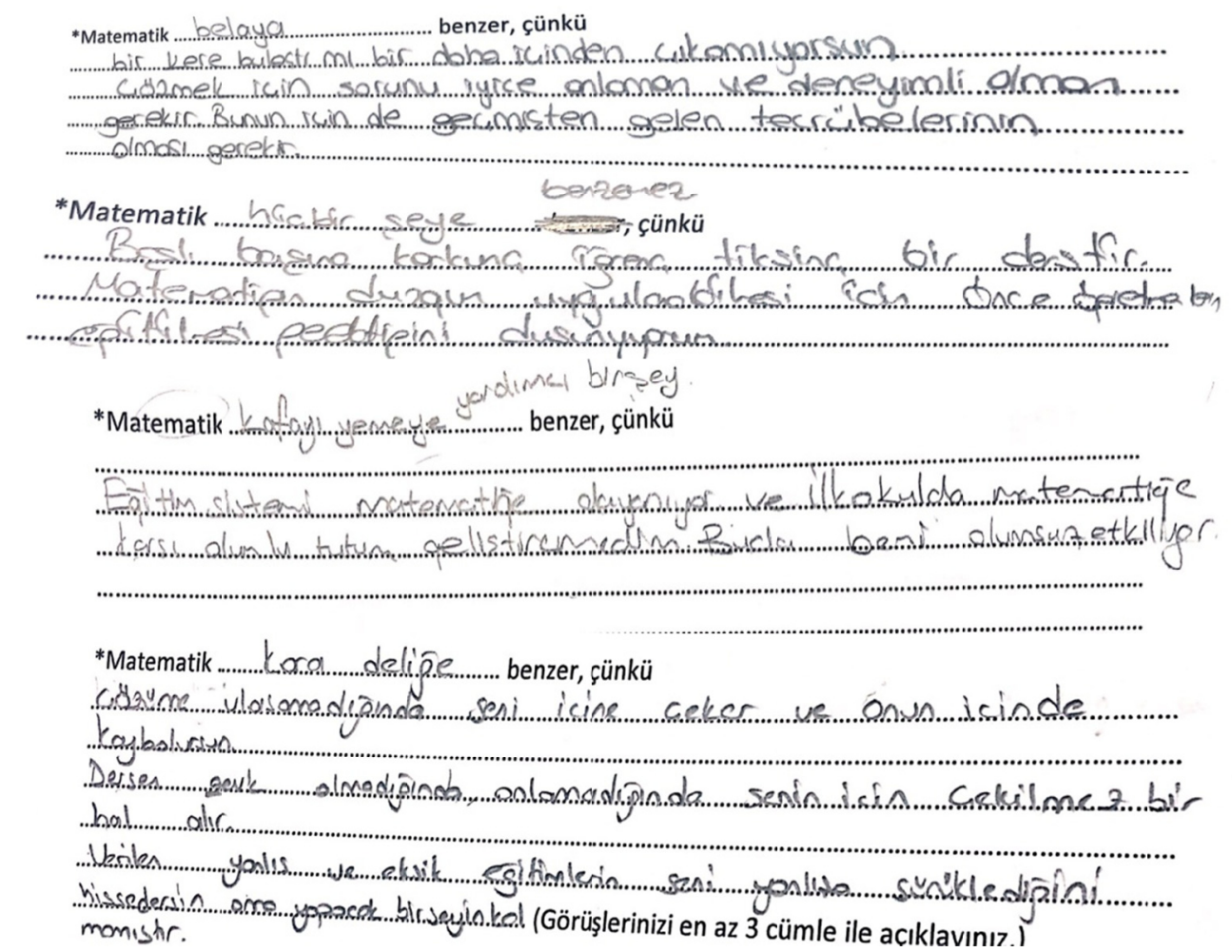

In the sub-theme of attributing importance to pre-requisite relations, mathematics was associated with driving and construction by the prospective teachers in both grades. As Altun (2005) notes, subjects in mathematics have a stronger prerequisite relations than other subjects. No concept can be learned completely before learning the other concepts that are assumed to be its prerequisite. 


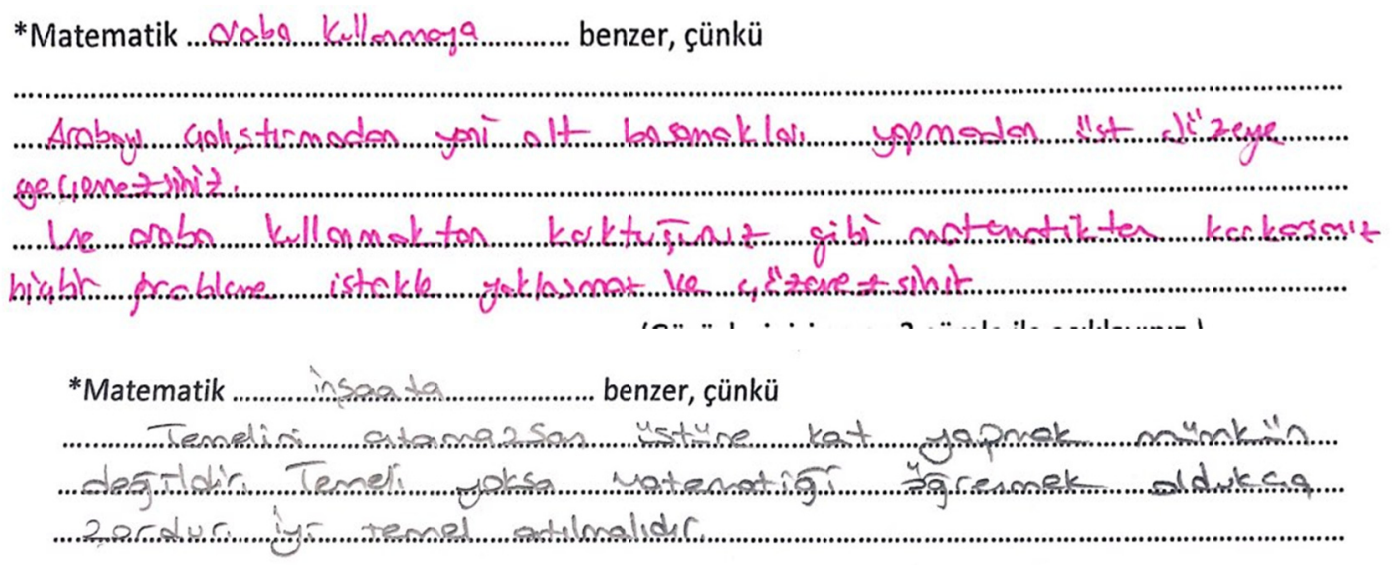

Regarding the sub-theme of establishing conceptual bases, Altun (2005) asserts that mathematics has its own language, which includes many basic concepts. The prospective teacher who associated mathematics with universal language "Its operations are same everywhere in the world, and using this language helps us understand mathematical concepts without difficulty. It is integral to life and used as a tool."

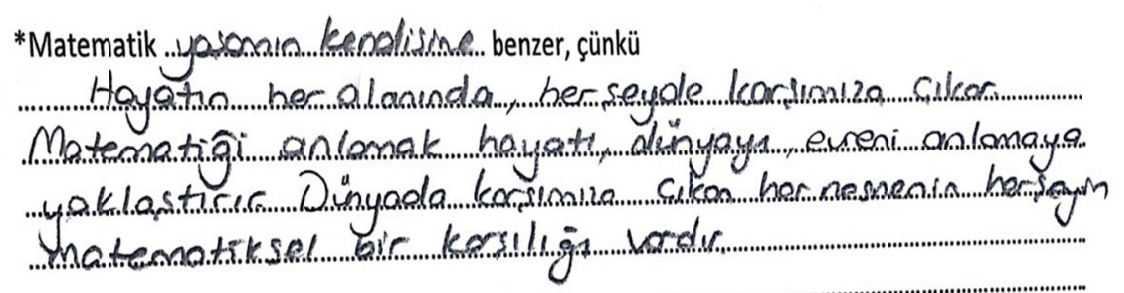

The mathematical knowledge theme includes the scope of mathematics and part-whole relations sub-themes. In the scope of mathematics sub-theme, the prospective teachers used creative metaphors such as friend, undiscovered island, knot, life, game, crossword puzzle, internet, a hard racetrack, space, world, matyroshka doll, closed box, Rubik's Cube, balance scale, deserted island, everything that seems easy but is hard, poem, a deep ocean, dance of numbers and machine. The reasons for such a variety of metaphors may be the very large scope of mathematics and its easy association with other subjects and daily life.
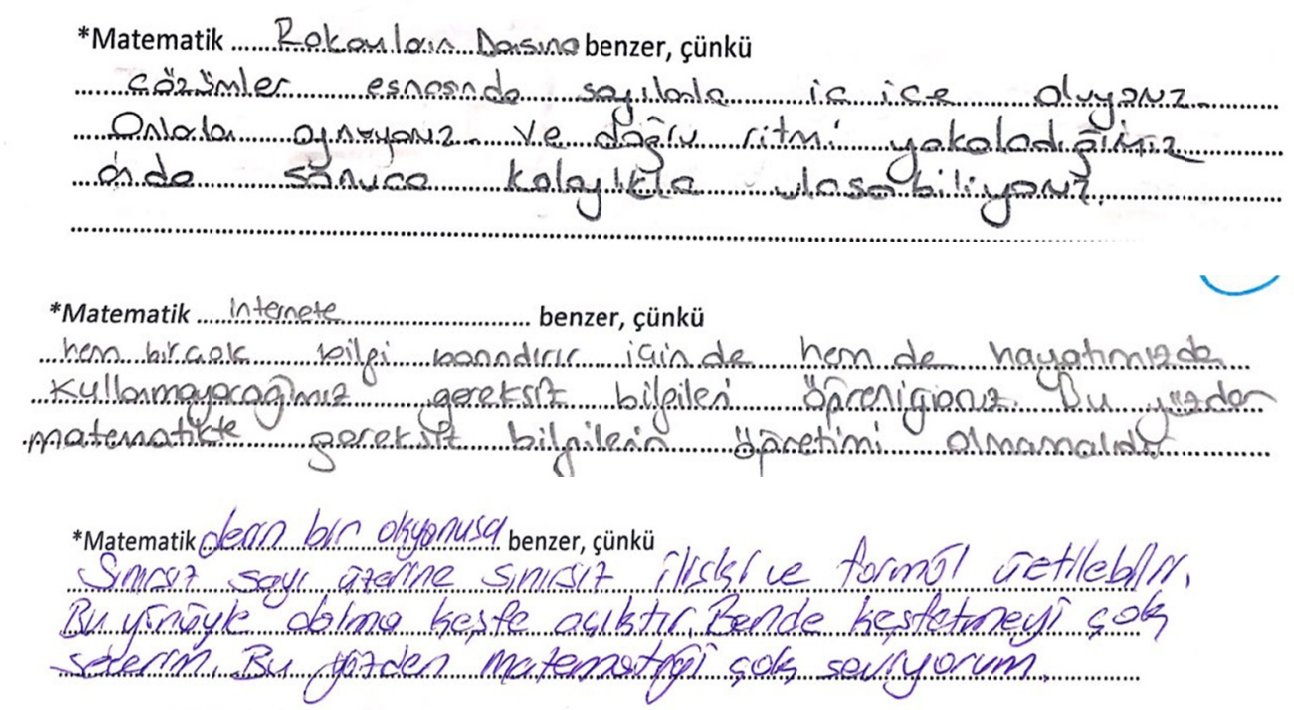

In the sub-theme of part-whole relations, there are metaphors such as sudoku, puzzle, dominoes, maze and crossword puzzle. The prospective teacher who used the dominoes metaphor explained that mathematics consist of pieces that complete each other, if a problem with some piece occurs, then the system will be incomplete, and its integrity will be destroyed.

The basic mathematical skills theme includes the reasoning, associating with daily life and problem solving sub-themes. Metaphors such as life, crossword puzzle, jumping rope, water, flower, closed box and Rubik's 
Cube were used. Like in other themes, the metaphors, life and crossword puzzle, were used by the prospective teachers from both grades in this theme. An explanation for the life metaphor is presented below. The other examples are related to the closed box and jumping rope metaphors.

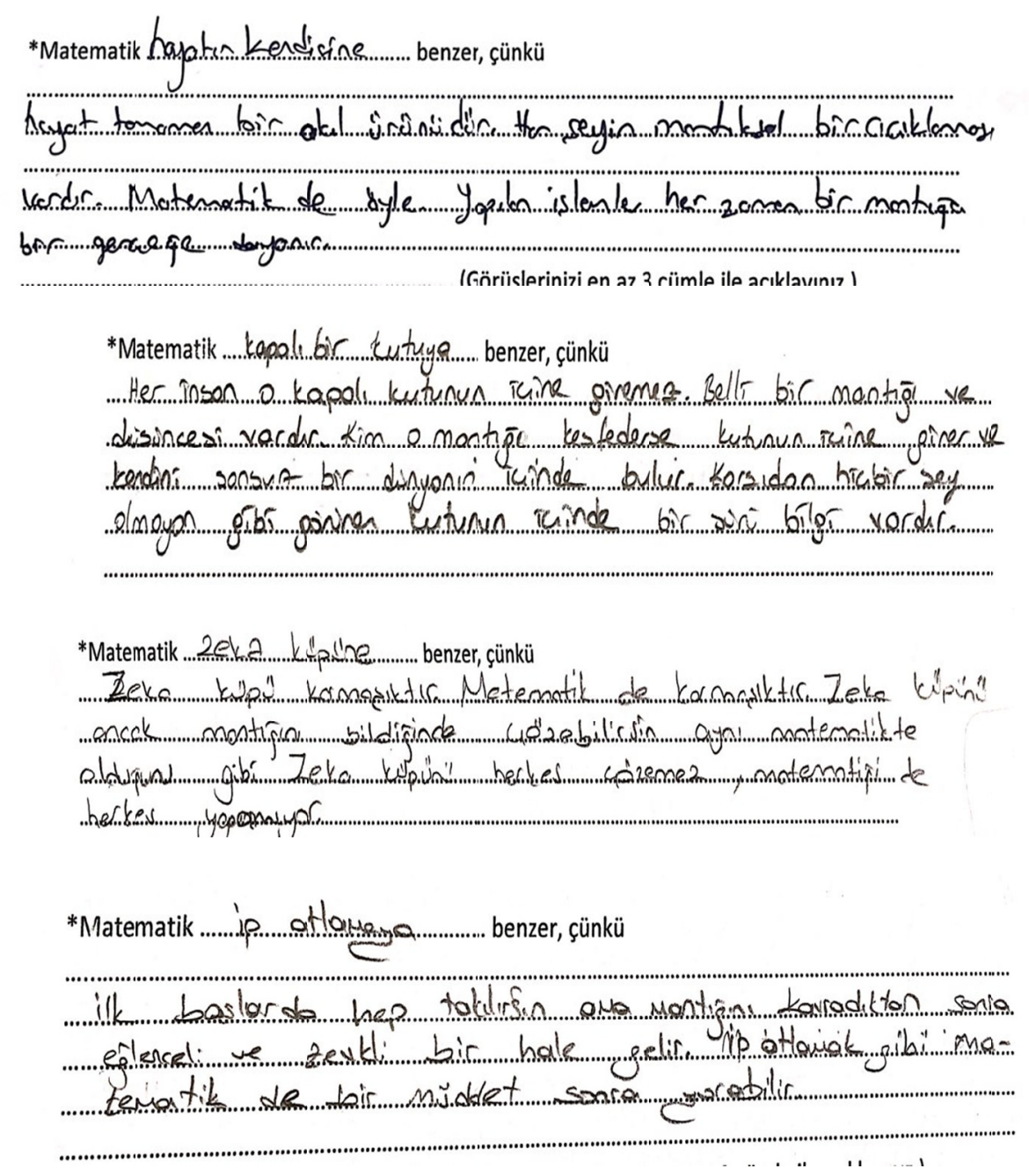

The main objectives of mathematics education are to teach individuals to be able to use mathematics in daily life, to produce effective solutions for real life problems, to understand events and cause-effect relationships in them and to develop their own ways of thinking using these skills. The use of life, stairs, everything that seems easy but is hard, game, rainbow, universal language, water, the root of a tree and oxygen as metaphors by the prospective primary school teachers shows that they are aware of these objectives. Regarding the sub-theme of associating with daily life, the result that the metaphor, life, was used $6 \%$ of the time is an important finding that overlaps with the nature of mathematics. Some examples are given below.

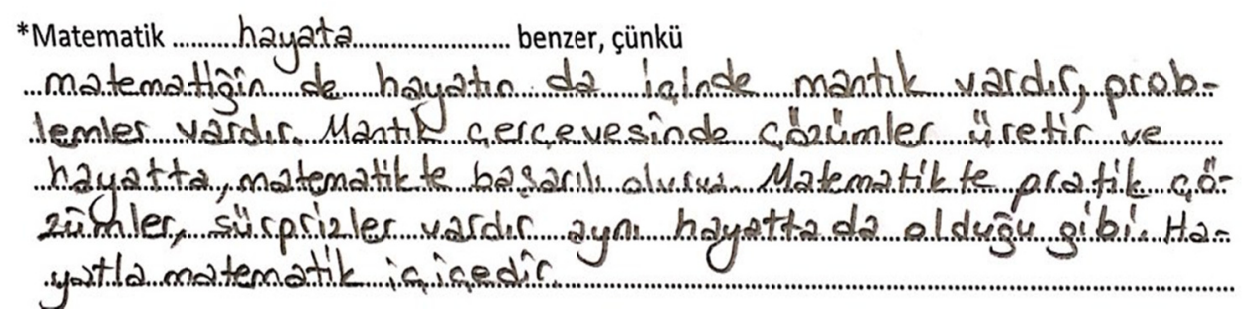



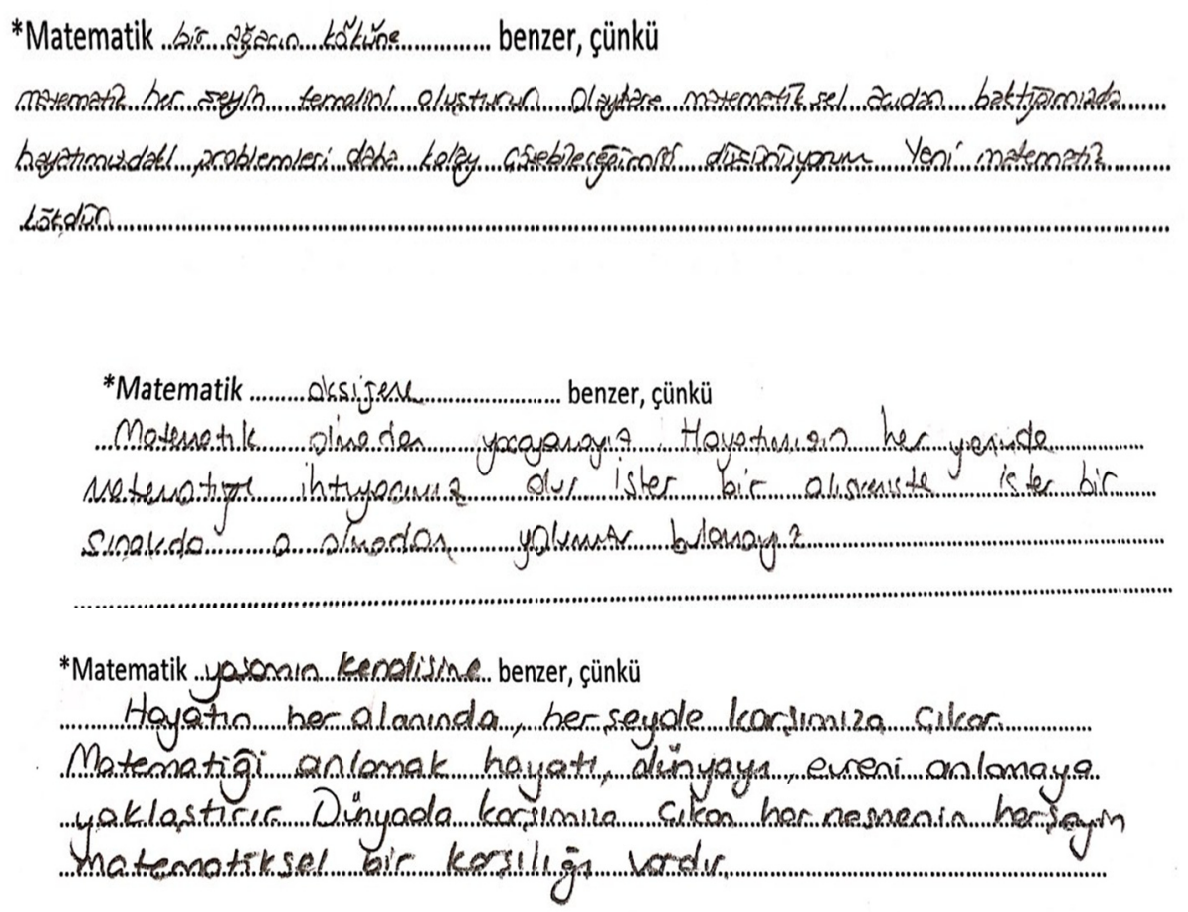

Problems and problem-solving process are important in every phase of teaching. Especially mathematics is used as a way for individuals to develop skills for solving problems that they come across in daily life (Türnüklü \& Yeşildere, 2005). In every phase of primary education, mathematical reasoning and problem solving are among the most important subjects in mathematics (Schmidt \& Bednarz, 1997; cited by Türnüklü \& Yeşildere, 2005). Understanding mathematical knowledge and forming relationships between its components take place in the problem-solving process (Swings \& Peterson, 1988). The emergence of the problem solving sub-theme as a result of data analysis is a pleasing finding. Game, world, life, crossword puzzle, matryoshka doll, madman, maze, stuffed grape leaves, Rubik's Cube, dance numbers, trouble, human brain and amusement park were the metaphors used by the prospective primary school teachers in the problem solving sub-theme. Examples of the metaphors used by the prospective teachers and their explanations are given below.

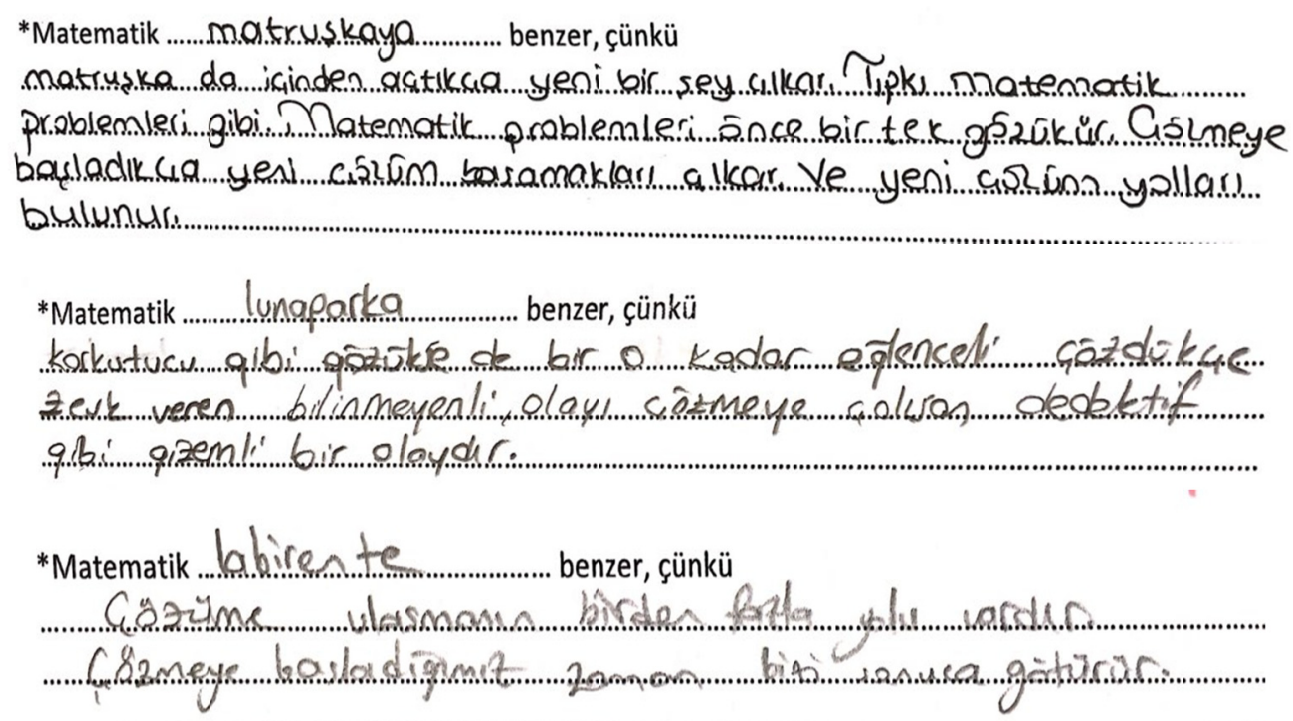




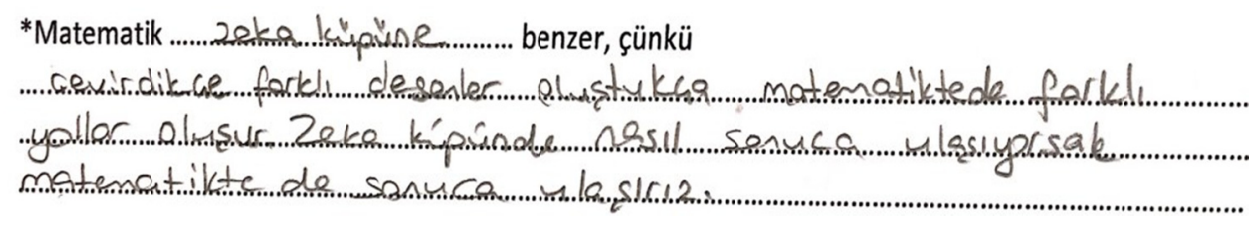

Table 5. A comparison of metaphorical perceptions by class level and themes

\begin{tabular}{lcccccc}
\hline \multirow{3}{*}{ Themes } & \multicolumn{5}{c}{ Metaphorical Perceptions } \\
\cline { 2 - 7 } & 4th grade prospective teachers & 3rd grade prospective teachers & \multicolumn{2}{c}{ Total } \\
\cline { 2 - 7 } & $\mathrm{f}$ & $\%$ & $\mathrm{f}$ & $\%$ & $\mathrm{f}$ & $\%$ \\
\hline The basic principles of mathematics teaching & 54 & 32,51 & 24 & 14.47 & 78 & 46.98 \\
Mathematical knowledge & 16 & 9.63 & 13 & 7.84 & 29 & 17.47 \\
Basic mathematical skills & 28 & 16.86 & 31 & 18.69 & 59 & 35.55 \\
\hline Total & 98 & 59 & 68 & 41 & 166 & 100 \\
\hline
\end{tabular}

A total of 166 metaphors provided by the prospective primary school teachers were grouped under three categories based on their common traits. The distribution of the metaphors by theme indicates that $46.98 \%$ of metaphors are for the basic principles of mathematics teaching, 35.55\% of metaphors are for basic mathematical skills, and $17.47 \%$ of the metaphors are for mathematical knowledge. Although the fourth-grade prospective teachers' mathematics anxiety-apprehension scores are lower than those of the third-grade prospective teachers, they were able to produce more metaphors.

Since 2014, prospective teachers have been required to take the Teacher Field Knowledge Test-TFKT (Öğretmenlik Alan Bilgisi Testi-ÖABT) in addition to the Public Personnel Selection Examination-PPSE (Kamu Personeli Seçme Sinavi-KPSS) to be appointed as teachers. The TFKT asks mathematics questions. The reasons for the use of more metaphors by the fourth-grade prospective teachers may be that they were studying hard for this examination, and that they know more mathematics. It is remarkable that the fourth grade prospective teachers' negative and positive attitudes towards mathematics are higher in number than those of the third grade prospective teachers. Similarly, the prospective teachers who are thought to have more command of mathematics subjects contributed more to the sub-themes of attributing importance to prerequisite relations and the scope of mathematics under the theme of the basic principles in mathematics teaching. The basic mathematical skills theme with its sub-themes was stated equally by prospective teachers in both grades.

\subsection{Results and Interpretations for the Third Research Question}

The causes of the prospective teachers' mathematics anxiety-apprehension were analyzed using descriptive statistics. Of the prospective teachers, 13 were found to have no mathematics anxiety-apprehension. The view of a prospective teacher related to this finding is given below. In all examples there are same expression of "What are the causes of your mathematics anxiety-apprehension? (In terms of topics I do not understand, negative events you experience, teacher you do not like, wrong mathematics education, etc.)"

$$
\begin{aligned}
& \text { ** Matematiğe yönelik kaygılarınızın-endişelerinizin sebepleri nelerdir? (Anlamadığın konular, } \\
& \text { yaşadığın olumsuz olaylar, sevmediğin öğretmen, yanlış matematik eğitimi, vb. açısından) } \\
& \text { Matemotit dersine karsı bir kagg', endıse duymuyorm Benim iaın } \\
& \text { gìsel ve eglenceli bir ders }
\end{aligned}
$$

The views of 95 prospective teachers who were found to have mathematics anxiety-apprehension were examined, and the causes of their anxiety-apprehension were grouped under five themes and sub-themes. These themes are:
a) Teacher-related
b) Prospective teacher-related
c) Examination system-related
d) Mathematics program-related
e) School facilities-related 
Table 6 . The causes of the prospective primary teachers' mathematics anxiety-apprehension

\begin{tabular}{|c|c|c|c|c|}
\hline Theme & Sub-theme & $\begin{array}{l}\text { Frequency } \\
\text { (3rd grade) }\end{array}$ & $\begin{array}{l}\text { Frequency } \\
\text { (4th grade) }\end{array}$ & Total frequency \\
\hline \multirow{8}{*}{ Teacher-related } & Not endearing & 5 & 1 & 6 \\
\hline & Committing violence & 2 & 1 & 3 \\
\hline & Favoritism & 1 & 1 & 2 \\
\hline & Indifference & 1 & - & 1 \\
\hline & Complicating mathematics & 1 & - & 1 \\
\hline & Frequent change of teachers & 1 & - & 1 \\
\hline & Ignoring student levels & - & 1 & 1 \\
\hline & $\begin{array}{l}\text { Inability to choose the correct teaching } \\
\text { method }\end{array}$ & 5 & 11 & 16 \\
\hline Subtotal & & 16 & 15 & 31 \\
\hline \multirow{8}{*}{$\begin{array}{l}\text { Prospective } \\
\text { teacher-related }\end{array}$} & Making calculation errors & - & 4 & 4 \\
\hline & Weak conceptual knowledge & 1 & - & 1 \\
\hline & Incomprehension of subjects & 19 & 13 & 32 \\
\hline & Mathematics fear & 2 & 1 & 3 \\
\hline & Not allocating time for study & 1 & - & 1 \\
\hline & Prejudice & 2 & 1 & 3 \\
\hline & Inability to associate with real life & 1 & 1 & 2 \\
\hline & Lack of self-confidence & 3 & 5 & 8 \\
\hline Subtotal & & 29 & 25 & 54 \\
\hline \multirow{5}{*}{ Exam system-related } & Developing negative attitudes & 1 & - & 1 \\
\hline & $\begin{array}{c}\text { Inability to associate mathematics with } \\
\text { real life }\end{array}$ & 1 & - & 1 \\
\hline & Complicating mathematics & 1 & - & 1 \\
\hline & Memorization & - & 5 & 5 \\
\hline & Wrong education method & - & 1 & 1 \\
\hline Subtotal & & 3 & 6 & 9 \\
\hline $\begin{array}{l}\text { Mathematics } \\
\text { program-related }\end{array}$ & The intensity of mathematics subjects & 1 & 3 & 4 \\
\hline Subtotal & & 1 & 3 & 4 \\
\hline $\begin{array}{l}\text { School } \\
\text { facilities-related }\end{array}$ & Teachers' administrative duties & 1 & 1 & 2 \\
\hline Subtotal & & 1 & 1 & 2 \\
\hline & Total & 50 & 50 & 100 \\
\hline
\end{tabular}


Table 6 shows that, of all the reported causes of mathematics anxiety-apprehension: 32\% are teacher-related, 53\% are prospective teacher-related, $9 \%$ are examination system-related, $4 \%$ mathematics program-related and $2 \%$ of the views are school facilities-related. The analysis of the causes of prospective primary teachers' mathematics anxiety-apprehension shows that student-related mathematics anxiety-apprehension has the highest frequency and percentage. It is remarkable that prospective teachers in both grades emphasized incomprehension of mathematics subjects at a $32 \%$ frequency. The views related to this finding are presented below.

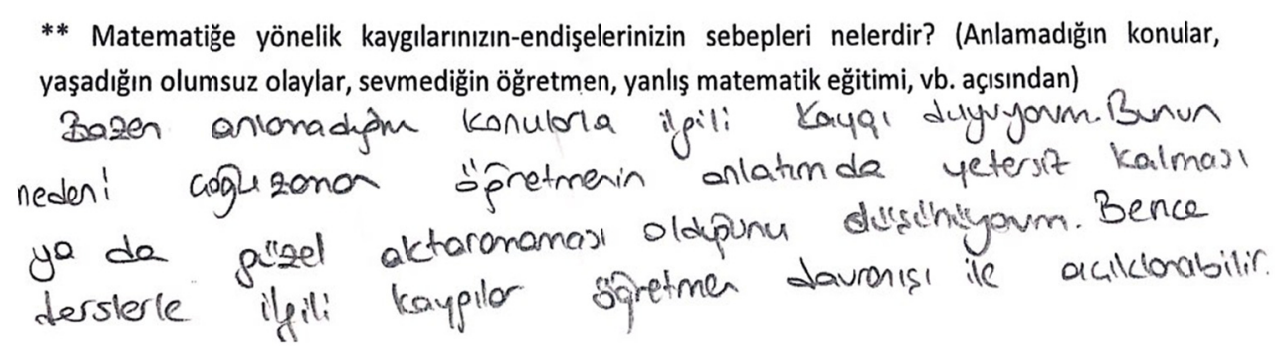

** Matematiğe yönelik kaygılarıııın-endişelerinizin sebepleri nelerdir? (Anlamadığın konular, yaşadığın olumsuz olaylar, sevmediğin öğretmen, yanlış matematik eğitimi, vb. açııından)

$$
\begin{aligned}
& \text { Zor kanulain anlasilmosinin gǘs olmosi ve yopanayoroim. disinmek }
\end{aligned}
$$

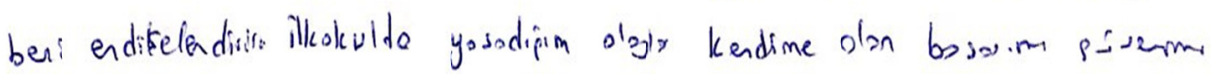

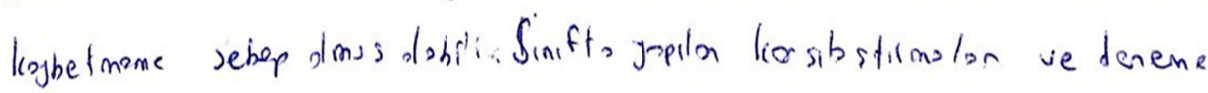

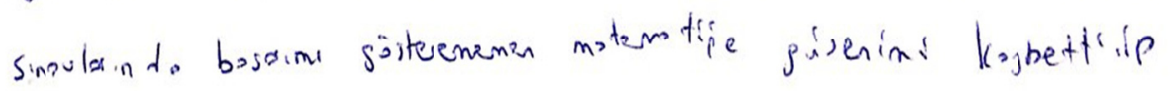

$$
\begin{aligned}
& \text { Sesmenenc netonid. }
\end{aligned}
$$

The second highest frequency for the causes of mathematics anxiety-apprehension was lack of self-confidence. One of the prospective teachers explained: "I have always been down because I cannot do mathematics." The prospective teachers saw mathematical calculation errors as a cause of their mathematics anxiety-apprehension. This is an example of their uneasiness with long solutions to problems.

The high frequency of identifying the inability of teachers to choose correct teaching method as a cause of mathematics anxiety-apprehension, $16 \%$, is notable. Examples of this view are provided below.

** Matematiğe yönelik kayglarııızın-endişelerinizin sebepleri nelerdir? (Anlamadı̈̆ı̆n konular,

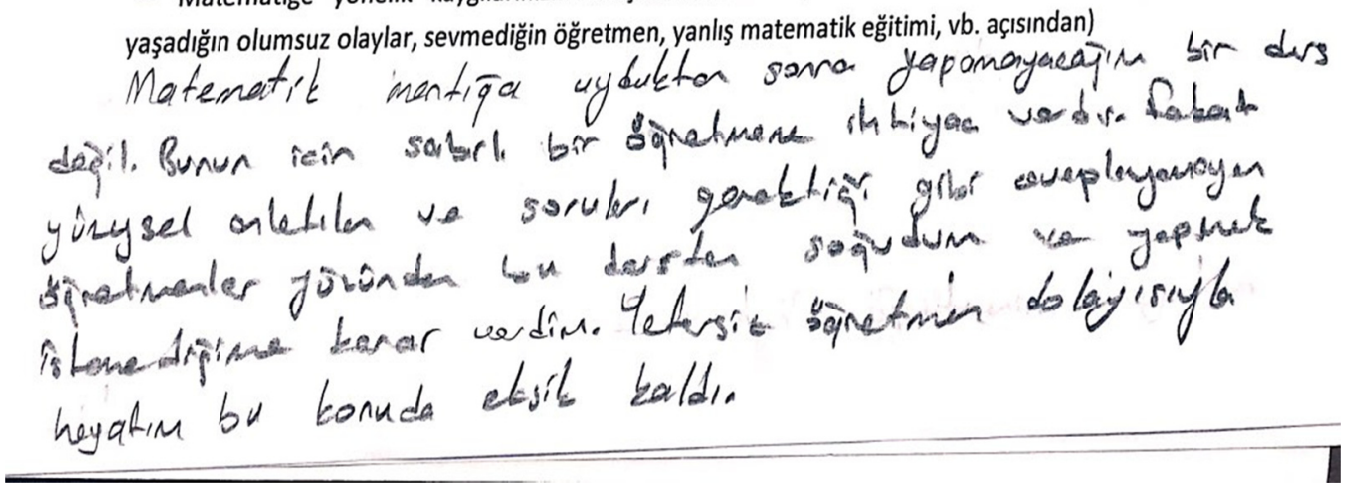
yaşadığın olumsuz olaylar, sevmediğin öğretmen, yanlış matematik eğitimi, vb. açısından) 
** Matematiğe yönelik kaygılarınızın-endişelerinizin sebepleri nelerdir? (Anlamadığın konular, yaşadığın olumsuz olaylar, sevmediğin öğretmen, yanlış matematik eğitimi, vb. açısından)

Matematik bpretiminde deretmenin bilgileri aktama

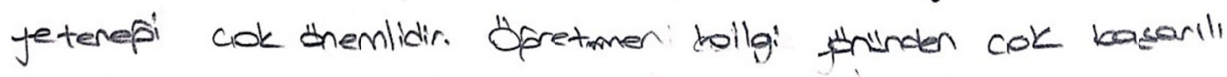
dsoda bilglerini aktaramadiktan soman b̈̈rena lain sadece iskencedi.

** Natematiğe yönelik kaygılarınızın-endişelerinizin sebepleri nelerdir? (Anlamadı̆̆ın konular, yaşadı̆̆ın olumsuz olaylar, sevmediğin öğretmen, yanlış matematik eğitimi, vb. açısından)

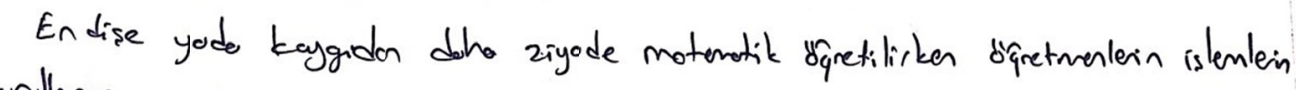

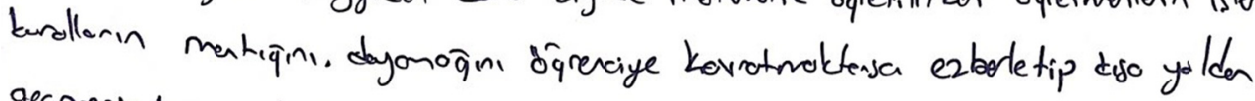
geamesinden rohotsizim. Her kurelin bir dayena ar kordor, Bir sağlomos vordir. Buntor

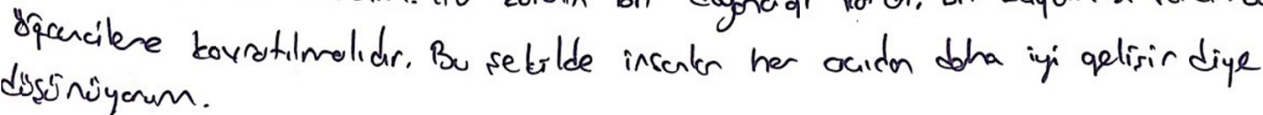

Table 6 shows that 5\% of the examination system-related reasons for mathematics anxiety-apprehension ( $9 \%$ ) were memorization. Examples of this view are provided below.

$$
\begin{aligned}
& \text { ** Matematiğe yönelik kaygılarınııı-endişelerinizin sebepleri nelerdir? (Anlamadığın konular, }
\end{aligned}
$$

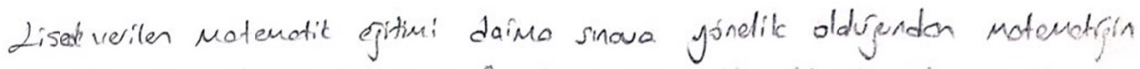

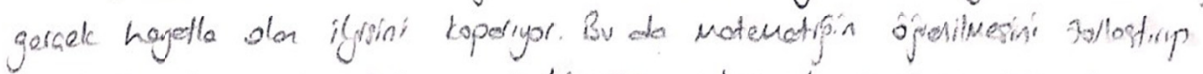

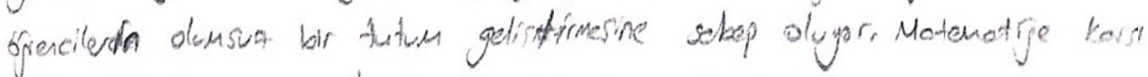

$$
\begin{aligned}
& \text { gelison bir onyergye yituck ise cot ar oluger. }
\end{aligned}
$$

** Natematiğe yönelik kaygılarınızın-endişelerinizin sebepleri nelerdir? (Anlamadığın konular, yaşadı̆ı̆ olumsuz olaylar, sevmediğin öğretmen, yanlış matematik eğitimi, vb. açısından)

$$
\begin{aligned}
& \text { Matematige karsi sok falb kaygi yasomiyorum ama beni kaygulandiracak } \\
& \text { durum yanlis matematik egitimi ile sadece ezbere dayall ginlük hayatla dayondirilmay? }
\end{aligned}
$$$$
\text { forklı forkh drneklerle aciklonmayon ögrenciye kendi yollarnı uygulaması iain }
$$$$
\text { firsat verilmeyen bir egitim beni kaygilondirir. }
$$

The intensity of mathematics subjects was remarkable among the mathematics program-related causes of mathematics anxiety-apprehension. A school facilities-related cause of mathematics anxiety-apprehension was found to be teachers' administrative duties. These causes compose $6 \%$ of those reported. Examples are given below.

** Matematiğe yönelik kaygılarınııın-endişelerinizin sebepleri nelerdir? (Anlamadığın konular, yaşadığın olumsuz olaylar, sevmediğin öğretmen, yanlı̧ matematik eğitimi, vb. açııından)

$$
\text { Konularin asiri yogun olmosi, bütün konularin úst üste ägretilmeye calisilmosi }
$$




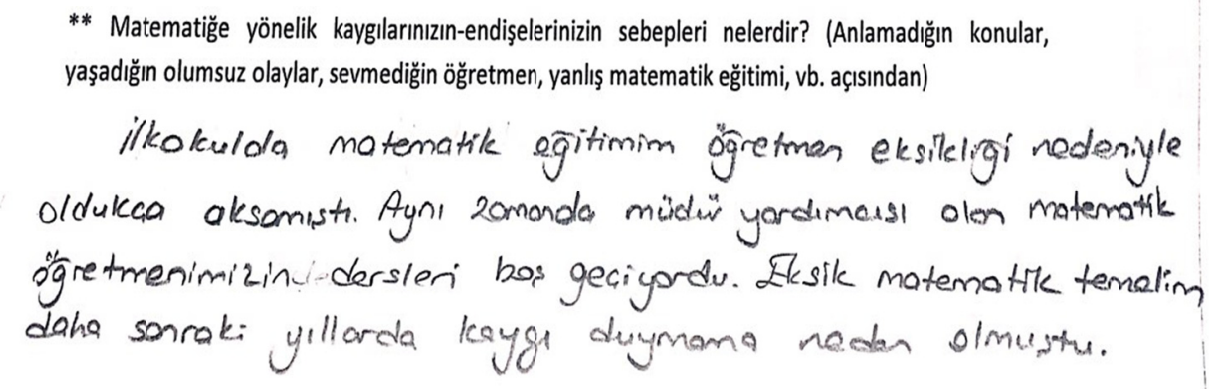

Committing violence by teachers as a cause for mathematics anxiety-apprehension is an interesting finding. It is worrisome for prospective teachers to liken mathematics to trouble and people they do not like. The prospective teachers who have experienced a violent environment have developed negative attitudes towards mathematics.

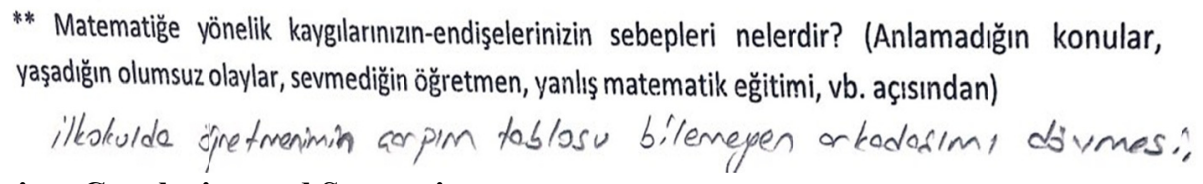

\section{Discussion, Conclusion and Suggestions}

The results of national and international research and assessments like The Programme for International Student Assessment (PISA) have shown that Turkish students at the primary level are not successful-especially in mathematics. PISA Wilson (2013) states that prospective primary school teachers have a high level of mathematics anxiety. They lack self-confidence in teaching mathematics and cannot mathematics effectively. Doruk and Kaplan (2013) focused on prospective primary school and primary school mathematics teachers' mathematics anxiety-apprehension and explored the prospective primary school teachers' mathematics anxiety-apprehension in terms of its sub-dimensions, comprehension, explaining, problem solving, arithmetical operations, self-efficacy, interpretation and making errors. Their results showed that both groups of prospective teachers had low levels of mathematics anxiety. The prospective primary school teachers had low levels of mathematics anxiety, except in the arithmetical operations sub-dimension in which they showed moderate level of anxiety. Bal-İncebacak and Ersoy (2016) evaluated the perspectives on mathematics teaching of prospective primary school teachers. They found that the themes for anxiety were: interest in mathematics, problems, apprehension, teacher attitudes, desperation, attitudes towards mathematics and mathematics. The main categories for the themes were: numbers and shapes, perceptions of mathematics, views of mathematics, attitudes towards mathematics, feelings for mathematics, interest in and relationship with mathematics.

The literature that summarizes the current situation indicates the need for examinations of prospective primary school teachers' mathematics anxiety-apprehension in detail. Few studies have explored prospective primary school teachers' mathematics anxiety-apprehension using qualitative and quantitative methods. Triangulating qualitative data from surveys and qualitative data-prospective teachers' metaphors for mathematics and reported causes of their mathematics anxiety-apprehension - is intended to increase the validity, reliability and originality of the study. This study's focus understands whether the prospective teachers' mathematics anxiety-apprehension differs in terms of some variables and the causes of their mathematics anxiety-apprehension. This study examined prospective primary school teachers' mathematics anxiety-apprehension in terms of gender, type of high school attended and class level and found that the prospective teachers' mathematics anxiety-apprehension significantly differed by type of high school attended (Anatolian high school) and class level (third grade), but that gender did not make any significant difference in mathematics anxiety-apprehension. These results are consistent with those of previous studies in the literature.

A review of literature shows that Brush (1978), Cooper and Robinson (1991), Ling (1982), Olson (1985), Singer and Stake (1986), Üldaş (2005), Sırmacı (2007), Peker and Halat (2008), Bal-İncebacak and Ersoy (2016) did not find statistically significant difference between mathematics anxiety-apprehension and gender. Alexander and Martray (1989), Baloğlu (2004), Eldemir (2006), Doruk and Kaplan (2013), Güven (2016), on the other hand, found that female prospective teachers had higher level of mathematics anxiety than male prospective teachers. Dikkartın-Övez (2012) concluded concluded that class level did not lead to any significant difference in students' mathematics anxiety-apprehension and also Doruk and Kaplan (2013) concluded that class level did not lead to any significant difference in prospective teachers' mathematics anxiety-apprehension. Küçük-Demir, Cansız, Deniz, Çevik-Kansu and İşleyen (2016) found that prospective primary school teachers' mathematics anxiety did not significantly differ by gender or type of high school attended, but did find a statistically significant difference 
by class level. Third-grade prospective teachers were found to have higher levels of mathematics anxiety. Bal-İncebacak and Ersoy (2016) found that male prospective teachers had higher levels of anxiety in the second and third grades, whereas female prospective teachers had higher levels of anxiety and all prospective primary school teachers had the highest levels in the fourth grade. Baloğlu (2004) found that female prospective teachers had higher scores in both general mathematics anxiety and mathematics test anxiety than male prospective teachers. However, for numerical calculations anxiety, male prospective teachers were found to have higher levels of anxiety than their female counterparts. There was no statistically significant difference between male and female prospective teachers for mathematics course anxiety.

These results indicate that mathematics anxiety is not an issue to be examined superficially, as noted by Baloğlu (2004).Scholars have summed up the causes of mathematics anxiety in three main categories: student-related, teacher-related and education-related (A. Harris \& J. Harris, 1987). Its causes have also been characterized as situational, dispositional and personal (Byrd, 1982). Keçeci (2011) suggests that the causes of mathematics anxiety are: "causes arising from the field," "causes arising from the structure of education and educators" and "causes arising from students themselves and their environment."

The secondary focus of the study is to explore mathematics anxiety-apprehension in detail. Its findings show that the prospective primary school teachers' mathematics anxiety-apprehension was related to teachers, the prospective teachers themselves, the examination system, the mathematics program and the school facilities.

One cause of teacher-related mathematics anxiety-apprehension is the inability of teachers to choose the correct teaching strategy. The prospective primary school teachers drew attention to their teachers' inability to transmit their mathematic knowledge accurately and effectively. The teaching methods used by teachers are highlighted by Baloğlu (2011) as highly important causes of raising the level of students' anxiety. Gresham (2010), Clark (2013) and Tretter (2012) also note that negative experiences of learning mathematics, negative classroom environment and negative teacher attitudes cause mathematics anxiety. Similarly, Zakaria et al. (2012) assert that mathematics anxiety has effects on mathematics success and that teachers should try to understand students to help them get rid of anxiety. Plaisance (2009) points out teachers' inability to teach mathematics entertainingly and poor attitudes. Bekdemir et al. (2004) emphasizes that students are heavily influenced by negative experiences with their teachers. Thus, teachers themselves serve as an important cause of students' mathematics anxiety. Regarding the efforts that teachers should make to understand their students, as Zakaria et. al. (2012) emphasize, the prospective primary school teachers in this study touched upon teacher-related causes when they described their teachers as: "not endearing, committing violence, playing favorites, indifferent, complicating mathematics, frequently changing and ignoring student levels." It is worrying that the idea of committing violence or favoritism is mentioned in the study. However, violence, favoritism and ignoring student levels are also encountered in the literature. This indicates teachers' mathematics teaching anxiety, a type of anxiety defined by Levine (1993) and Peker (2006) as anxiety experienced during the teaching of mathematical concepts, theorems, formulas or problem solving. Thus, when explaining the teacher-related causes of their mathematics anxiety, the prospective primary school teachers contributed to the finding in the literature that mathematics anxiety is transmitted by teachers (for example, Aiken,1976; Baydar \& Bulut, 2002; Berebitsky, 1985; Buhlman \& Young, 1982; Chaffee, 1986; Hackett, 1985; Kelly \& Tomhave, 1985, Lazarus, 1974; Karakaş, Türker \& Turanl1, 2008).

One of the prospective teacher-related causes of mathematics anxiety was the incomprehension of mathematics subjects. Similar results are in the literature. For example, Bal-Incebacak and Ersoy (2016) found that prospective primary school teachers are alienated from mathematics and have a feeling that they were unable not perform successfully as a result of negative experiences with their teachers. This leads to a lack of self-confidence, which the prospective primary school teachers described as another prospective teacher-related cause of mathematics anxiety-apprehension. The prospective primary school teachers' self-related causes were incomprehension of mathematics subjects and lack of self-confidence. Likewise, Peker (2006) stated that mathematics anxiety is related to factors such as mathematics field knowledge, attitudes towards mathematics and self-confidence. Clark (2013), Tretter (2012) and Plaisance (2009) associated mathematics anxiety with not forming relationships between mathematics and the real world.

The prospective primary school teachers who participated in the present study have similar views. The prospective teachers stated that calculations take a long time during problem solving, that they are seized with fear when they encounter different problems, and that they are biased in solving problems. These results suggest that the prospective primary school teachers are also affected negatively when learning about mathematics, which was also concluded by Rodrigues (2012) in a study of mathematics anxiety and fear. Understanding mathematical knowledge and forming relationships with this knowledge occurs during problem solving (Swings 
\& Peterson, 1988). To do problem solving, students should have the ability to gather the concepts and calculations needed (Bernardo, 1999). However, the prospective primary school teachers drew attention to two important points, memorized mathematics teaching that is unrelated to daily life and the intensity of the mathematics subjects in the mathematics program, when ranking the causes of their mathematics anxiety-apprehension. Prospective teachers and the students should do problems based on real life situations, and the feeling of being able to problem solving should be aroused to reduce mathematics anxiety-apprehension. The idea that mathematics is a part of daily life should be transmitted to prospective teachers and to students by learning by doing and experiencing the sense of wonder.

A review of the literature reveals that there are environmental, individual and ambient factors that contribute to mathematics anxiety (Cemen, 1987), and mathematics anxiety has different dimensions (problem solving, evaluation, mathematics tests, numbers, learning mathematics, passive monitoring and performance anxiety) (for example, Baloğlu, 2004). The prospective primary teachers provided examples of prior experiences that involve the sub-dimensions of mathematics anxiety when they were explaining their mathematics anxiety-apprehension. Uusimaki and Nason (2004) also explained that the causes of prospective primary school teachers' mathematics anxiety and negative ideas were experiences of learning mathematics in primary school. The prior experiences of the prospective primary school teachers served as starting points for the causes of their mathematics anxiety. The mathematics learning and teaching experiences of the prospective primary school teachers in this study can serve as a guide. Similar inferences have been made in the literature (Keklikçi \& Yılmazer, 2013; Putwain \& Symes, 2011; Hadley \& Dorward, 2011; Bates et. al., 2011; Peker \& Ertekin, 2011; McGlynn-Stewart, 2010; Bekdemir, 2010; Adnan \& Zakarai, 2010; Martino \& Zan, 2010; Gresham, 2009; Rule \& Harrell, 2006; Özçakır-Sümen, Çağlayan \& Kartal, 2015).

Another important step taken by this study was to explore mathematics anxiety-apprehension through metaphors. The examination of metaphorical perceptions showed that the third- and fourth-grade prospective primary school teachers used the life, crossword puzzle, game and human metaphors frequently for each sub-theme, and a total of 166 metaphors were identified. The themes including the highest number of metaphors were the basic principles of mathematics teaching, basic mathematics skills and mathematical knowledge, respectively. The fourth-grade prospective primary school teachers' production of a higher number of metaphors under the theme of the basic principles of mathematics teaching was evaluated to see whether they have negative or positive attitudes towards mathematics. This negatively correlates with their lower levels of anxiety than those of third grade prospective teachers. The fourth grade prospective primary school teachers who are expected to take PPSE and TFKT, and thus have a high level of mathematics anxiety, produced more metaphors, which could be explained by their broader knowledge of the mathematics field. The fourth-grade prospective primary school teachers also mentioned the sub-theme of attributing importance to prerequisite relations in mathematics more frequently. The metaphors used in the other themes were equal in number in terms of class level.

Similar inferences have been made in the literature. For example, in a study conducted by Özçakır-Sümen, Çağlayan and Kartal (2015) to analyze prospective primary school teachers' mathematics fear, metaphorical perceptions were grouped under the themes of life, games and difficulty. Güveli et al. (2011) investigated prospective primary school teachers' metaphorical perceptions related to mathematics and found perceptions of mathematics as an exciting course and as a boring and difficult course. Mathematics as a course that includes many subjects was also prominent among the prospective primary school teachers' metaphorical perceptions. Şahin (2013) found that prospective teachers associated mathematics with intelligence, being enjoyable, being necessary, difficulty and success, and least frequently associated it with being unnecessary, easiness and authority. The students in the department were separated into three groups depending on their metaphors for mathematics, and the prospective primary school teachers were found to associate the concept of mathematics with positive metaphors.

In learning and teaching mathematics, the most important problem is said to be mathematics anxiety (Baloğlu, 2001). Thus, prospective teachers' level of mathematics teaching anxiety should be reduced before they start their profession, and they should only start teaching after having been successful and gained self-confidence in their fields (Peker, 2006). For this reason, this study's results are crucial for future generations to learn mathematics without any anxiety, apprehension or fear. Its results will contribute to the literature and guide further research.

\section{References}

Adnan, M. \& Zakaria, E. (2010). Exploring beliefs of pre-service Mathematics teachers: A Malaysian perspective. Asian Social Science. https://doi.org/10.5539/ass.v6n10p152 
Aiken, L. R. (1976). Update on Attitudes and Other Affective Variables in Learning Mathematics. Review of Educational Research, 46, 293-311. https://doi.org/10.3102/00346543046002293

Alexander, L., \& Martray, C. (1989). The development ofan abbreviated version of the Mathematics Anxiety Rating Scale. Measurement and Evaluation in Counseling and Development, 22, 143-150.

Alkan, V. (2010). Matematikten nefret ediyorum! Pamukkale Üniversitesi Eğitim Fakültesi Dergisi, 28(11), 189-199.

Altun, M. (2005). İlköğretim İkinci Kademede (6, 7 ve 8.sinıflarda) Matematik Öğretimi (4. baskı). Bursa: Aktüel Yayınevi.

Bal-İncebacak, B., \& Ersoy, E. (2016). Matematik neden beni kaygılandırır? Hasan Ali Yücel Eğitim Fakültesi Dergisi, 13-2(25),1-15.

Baloğlu, M. (2001). Matematik korkusunu yenmek. Kuram ve Uygulamada Eğitim Bilimleri Dergisi, 1(1), 59-76.

Baloğolu, M. (2004, 6-9 Temmuz). Üniversite öğrencilerinin matematik kaygı düzeyleri açısından karşılaş̧tırılması. XIII. Ulusal Eğitim Bilimleri Kurultayı. İnönü Üniversitesi, Eğitim Fakültesi, Malatya.

Bates, A. B., Latham, N. \& Kim, J. (2011). Linking preservice teachers' mathematics self-efficacy and mathematics teaching efficacy to their mathematical performance. School Science and Mathematics. https://doi.org/10.1111/j.1949-8594.2011.00095.x

Baydar, S. C., \& Bulut, S. (2002). Öğretmenlerin Matematiğin Doğası ve Öğretimi ile ilgili İnançlarının Matematik Eğitimindeki Önemi. Hacettepe Üniversitesi Eğitim Fakültesi Dergisi, 23, 62-66.

Bekdemir, M. (2010). The pre-service teachers' mathematics anxiety related to depth of negative experiences in mathematics classroom while they were students. Educ Stud Math. https://doi.org/10.1007/s10649-010-9260-7

Bekdemir, M., Işık, A., \& Çıkı1ı, Y. (2004). Matematik kaygısını oluşturan ve artıran öğretmen davranışları ve çözüm yolları. Eğitim Araştırmaları Dergisi, 4(16), 88-89.

Berebitsky, R. D. (1985). An Annotated Bibliography of the Literature Dealing With Mathematics Anxiety. ERIC Document Reproduction Service No. ED 257684.

Bernardo, A., B. (1999). Overcoming Obstacles in Understanding and Solving Word Problems in Mathematics. Educational Psychology. https://doi.org/10.1080/0144341990190203

Bohuslav, R. V. (1980). A Method for Dealing with Attitudes and Anxieties in Mathematics. Ed. D. Practicum, Nova University.

Brewer, J., \& Hunter, A. (1989). Multimethod Research: A Synthesis of Styles. Newbury Park: Sage.

Brush, L. R. (1978). A validation study of the mathematical anxiety rating scale (MARS). Educational and Psychological Measurement. https://doi.org/10.1177/001316447803800236

Buhlman, B. J., \& Young, D. M. (1982). On the Transmission of Mathematics Anxiety. Arithmetic Teacher. ERIC Number: EJ270201.

Burton, G. (1984). Revealing Images. School Science and Mathematics, 84(3), 199-207. https://doi.org/10.1111/j.1949-8594.1984.tb09541.x

Büyüköztürk, Ş. (2006). Sosyal Bilimler için Veri Analizi El Kitabı (6. Baskl). Ankara: PegemA Yayıncılık.

Byrd, P. (1982). A Descriptive Study of Mathematics Anxiety: Its Nature and Antecedents (Unpublished PhD Thesis). Indiana University.

Cemen, P. B. (1987). The nature of mathematics anxiety. ERIC documentDissertation. ED. 287729

Chaffee, D. D. (1986). An Annotated Bibliography of Material Dealing With Mathematics Anxiety. ERIC Document Reproduction Service No. ED 277596.

Clark, M. (2013). Teaching the math anxious female student: Teacher beliefs about math anxiety and strategies to help female students in all-girls schools (The degree of master of teaching). The Department of Curriculum, Teaching and Learning, Ontario Institute for Studies in Education (OISE), University of Toronto, Canada.

Cooper, S., \& Robinson, D. (1991). The Relationship of Mathematics Self-Efficacy Beliefs to Mathematics Anxiety and Performance. Measurement and Evaluation in Counseling. . 
Dikkartin-Övez, F. T. (2012). An Examination on the Relation Between Mathematics Anxiety and Achievements of 5th, 6th, 7th and 8th Grade Students. International Mathematical Forum, 7(60), 2987-2994.

Doruk, M., \& Kaplan, A. (2013). Sınıf ve ilköğretim matematik öğretmeni adaylarının matematik kaygılarının incelenmesi. Kastamonu Eğitim Dergisi, 21(4)(Özel Sayı), 1505-1522.

Eldemir, H. H. (2006). Sinıf öğretmeni adaylarının matematik kaygısının bazı psiko-sosyal değişkenler açısından incelenmesi (Unpublished Master thesis). Cumhuriyet Üniversity, Social Sciences Institute, Sivas.

Fennema, E., \& Sherman, J. A. (1976). Fennema-sherman mathematics attitudes scales: Instruments designed to measure attitudes toward the learning of mathematics by females and males. Journal for Research in Mathematics Education, 7(5). https://doi.org/10.2307/748467

Fitzgerald, S. M. (1997). The Relationship between Anxiety and Statistics Achievement: A Meta-Analysis. (Unpublished Ph. D. thesis). University of Toledo.

Greenwood, J. (1984). My Anxieties about Math Anxiety. Mathematics Teacher. ERIC Number: EJ309089

Gresham, G. (2009). An examination of mathematics teacher efficacy and mathematics anxiety in elementary pre- service teachers. Journal of Classroom Interaction.

Gresham, G. (2010). A study exploring exceptional education pre-service teachers' mathematics anxiety.

Güveli, E., İpek, A. S., \& Atasoy, E. (2011). Sınıf öğretmeni adaylarının matematik kavramına yönelik metafor algilar1. Turkish Journal of Computer and Mathematics Education, 2(2), 140-159.

Güven, E. (2016). Anxiety and piano exams: Turkish prospective music teachers' experiences. Music Education Research, 18(3), 305-316. https://doi.org/10.1080/14613808.2015.1122748

Hackett, G. (1985). Role of Mathematics Self-Efficacy in the Choice of Math Related Majors of College Women and Men: A Path Analysis. Journal of Counseling Psychology. https://doi.org/10.1037/0022-0167.32.1.47

Hammersley, M., \& Atkinson, P. (1995). Ethnography: Principles in Practice (2nd ed.). London: Routledge.

Hannula, M. (2005). Affect in mathematical thinking and learning. The Future of Mathematics Education and Mathematics Learning. BIFEB Strobl. Austria, August.

Harris, A., \& Harris, J. (1987). Reducing Mathematics Anxiety With Computer Assisted Instruction. Mathematics and Computer Education, 21, 16-24.

Ikegulu, T. N. (1998). An Empirical Development of an Instrument to Assess Mathematics Anxiety and Apprehension.

Işık, A., Çiltaş, A., \& Bekdemir, M. (2008). Matematik Eğitiminin Gerekliliği ve Önemi. Kazım Karabekir Ĕ̈itim Fakültesi Dergisi, 17.

Karakaş-Türker, N. \& Turanlı, N. (2008).Matematik eğitimi derslerine yönelik tutum ölçeği geliştirilmesi. Gazi Eğitim Fakültesi Dergisi, 28(3), 17-29.

Karakaya, İ. (2009). Bilimsel Araştırma Yöntemleri, Bölüm III, p.59. Editör: Tanrı̈ğğen, A. (2009). Bilimsel Araştırma Yöntemleri (1.baskl). Ankara: Anı Yayıncılık.

Keçeci, T. (2011). Matematik kaygısı ve korkusu ile mücadele yolları. II. International Conference on New Trends in Educational on Their Imlications sunulan bildiri. Antalya.

Keklikçi, H., \& Yılmazer, Z. (2013). İlköğretim öğrencilerinin matematik korku düzeyleriyle matematik öğretmenlerine yönelik görüşleri arasındaki ilişkinin belirlenmesi. Journal of Research in Education and Teaching, 2(3), 198-204.

Kelly, W. P., \& Tomhave, W. K. (1985). A Study of Math Anxiety/Math Avoidance on Pre-Service Elementary Teachers. Arithmetic Teacher, 32(5), 51-53.

Kogelman, S. \& Warren, J. (1979). Mind Over Math. New York, McGraw-Hill.

Küçük-Demir, B., Cansız, Ş., Deniz, D., Çevik-Kansu, C., \& İşleyen, T. (2016). Sınıf Öğretmeni Adaylarının Matematik Öğretmeye Yönelik Kaygılarının Farklı Değişkenler Açısından İncelenmesi (Bayburt Örneği). Bayburt Ĕ̈itim Fakültesi Dergisi, 11(2), 379-390.

Lazarus, M. (1974). Mathophobia: some personal speculations. National Elementary Principal, 53(2), 16-22.

Levine, G. (1993). Prior mathematics history, anticipated mathematics teaching style, and anxiety for teaching mathematics among preservice elementary school teachers. Paper presented at the Annual Meeting of the 
International Group for Psychology of Mathematics Education, North American Chapter. (ERIC Document Reproduction Service No. ED373972).

Ling, J. L. (1982). A Factor Analytic Study of Mathematics Anxiety (Unpublished Ph.D. Thesis). Virginia Polytechnic Institute and State University.

Martino, P. D., \& Zan, R. (2010). 'Me and maths': towards a definition of attitude grounded on students' narratives. $J$ Math Teacher Education, 13(1), 27-48. https://doi.org/10.1007/s10857-009-9134-z

McGlynn-Stewart, M. (2010). Listening to Students, Listening to Myself: Addressing pre-service teachers' fears of mathematics and teaching mathematics. Studying Teacher Education, 6(2), 175-186. https://doi.org/10.1080/17425964.2010.495898

Miles, M. B., \& Huberman, A. M. (1994). Qualitative data analysis: A sourcebook of new methods (2nd ed.). Thousand Oaks, CA: Sage.

Olson, J. F. (1985). Causes and Correlates of Mathematics Anxiety and Mathematics Achievement: A Path Analytic Approach (Unpublished PhD. Thesis). University of Nebraska.

Özçakır-Sümen, Ö., Çağlayan, K. T., \& Kartal, A. (2015). Sınıf Öğretmeni Adaylarının Matematik Korkuları. Hacettepe Üniversitesi Ĕgitim Fakültesi Dergisi (H. U. Journal of Education), 30(2), 69-80.

Özdemir, E., \& Gür, H. (2011). Matematik Kaygısı-Endişesi Ölçeğinin (MKEÖ) Geçerlik ve Güvenirlik Çalışması. Ĕgitim ve Bilim, 36(161), 39-50.

Patton, Q. M. (1990). Qualitative Evaluation and Re- search Methods (2nd ed.), London: Sage Publication.

Peker, M. (2006). Matematik öğretimine yönelik kaygı ölçeğinin geliştirilmesi. Eğitim Bilimleri ve Uygulama Dergisi, 5(9), 73-92.

Peker, M., \& Ertekin, E. (2011). The relationship between mathematics teaching anxiety and mathematics anxiety. The New Educational Rewiev, 23(1), 213-226.

Peker, M., \& Halat, E. (2008). The pre-service elementary school teachers' mathematics teaching anxiety and gender. The European Conference on Educational Research, Goteborg, Sweden.

Plaisance, D. V. (2009). Mathematics anxiety of preservice elementary teachers after comp- leting a problem solving course. Louisiana Association of Teachers of Mathematics (LATM) Journal, 5(1). Retrieved from http://www.lamath.org/journal/vol5no1/Math_Anxiety.pdf

Rodrigues, K. J. (2012). It does matter how we teach math. Journal of Adult Education, 41(8), 29-33.

Rule, A. C., \& Harrell, M. H. (2006). Symbolic drawings reveal changes in preservice teacher mathematics attitudes after a mathematics methods course. School Science and Mathematics Journal, https://doi.org/10.1111/j.1949-8594.2006.tb17913.x

Şahin, B. (2013). Öğretmen adaylarının "matematik öğretmeni”, "matematik" ve "matematik dersi" kavramlarına ilişsin sahip oldukları metaforik algılar. Mersin Üniversitesi Ĕ̈itim Fakültesi Dergisi, 9(1), 313-321.

Shodahl, S. A., \& Diers, C. (1984). Math Anxiety in College Students: Sources and Solutions. Community College Review, 12(2), 32-36. https://doi.org/10.1177/00915521840120020

Sırmacı, N. (2007). Üniversite Öğrencilerinin Matematiğe Karşı Kaygı ve Tutumlarının İncelenmesi: Erzurum Örneği. Eğitim ve Bilim, 32, 53-70.

Skemp, R. (1971). The Psychology of Mathematics. Baltimore, Penguin Books.

Skiba, A. (1990). Reviewing an Old Subject: Math Anxiety. Mathematics Teacher, 83(3), 188-189. Retrieved from https://eric.ed.gov/?id=EJ409383

Strawderman, V. W. (1985). A Description of Mathematics Anxiety Using an Integrative Model (Unpublished PHD Thesis). Georgia State University.

Swings, S., \& Peterson, P. (1988). Elaborative and Integrative Thought Processes in Mathematics Learning. Journal of Educational Psychology, 80(1), 54-66. https://doi.org/10.1037/0022-0663.80.1.54

Tobias, S. (1998). Anxiety and mathematics. Harvard Education Review, 50, 63-70. https://doi.org/10.17763/haer.50.1.xw483257j6035084

Tretter, J. D. (2012). Mathematics anxiety in ninth-grade pre-algebra. Masters Theses \& Specialist Projects. Paper 1165. 
Türnüklü, E. B., \& Yeşildere, S. (2005). Problem, Problem Çözme ve Eleştirel Düşünme. Gazi Eğitim Fakültesi Dergisi, 25(3), 107-123.

Üldaş, İ. (2005). Öğretmen ve ögretmen adaylarına yönelik matematik kaygı ölçeği (MKÖ-Ö) 'nin geliştirilmesi ve matematik kaygısına iliş̧kin bir değerlendirme (Unpublished Master thesis). Marmara University, Educational Science Institute, İstanbul.

Uusimaki, L., \& Nason, R. (2004). Causes underlying pre-service teachers' negative be- liefs and anxieties about mathematics. Proceedings of the 28th Conference of the International Group for the Psychology of Mathematics Education, 4, 369-376.

Williams, W. V. (1988). Answers to Questions About Math Anxiety. School Science and Mathematics, 88(2), 95-104. https://doi.org/10.1111/j.1949-8594.1988.tb11786.x

Wilson, S. (2013). Mature age pre-service teachers' mathematics anxiety and factors impacting on university retention. In V. Steinle, L. Ball, \& C. Bardini (Eds.), Mathematics education: Yesterday, today and tomorrow. Proceedings of the 36th annual conference of the Mathematics Education Research Group of Australasia, 666-673. Melbourne, VIC: MERGA

Yıldırım, A., \& Şimşek, H. (2008). Sosyal Bilimlerde Nitel Araştırma Yöntemleri. Ankara: Seçkin Yayınevi.

Yüksel-Şahin, F. (2004). Ortaöğretim öğrencilerinin ve üniversite öğrencilerinin matematik korku düzeyleri. Educational Sciences and Practice, 3(5), 57-74.

Zacharias, J. (1976). Apples, Oranges, and Abstractions: A Matter of Math. National Elementary Principal, 56(1), 20-27.

Zakaria, E. \& Nordin, N. M. (2008). The Effects of Mathematics Anxiety on Matriculation Students as Related to Motivation and Achievement. EURASIA Journal of Mathematics, Science \& Technology Education, 4(1), 27-30.

Zakaria, E., Zain, N. M., Ahmad, N. A., \& Erlina, A. (2012). Mathematıcs anxiety and achievement among secondary school students. American Journal of Applied Sciences, 9(11), 1828-1832. https://doi.org/10.3844/ajassp.2012.1828.1832

\section{Note}

Note 1. This study was presented at the 16th International Primary Teacher Education Symposium (USOS 2017, 8-11 May, Cyprus).

\section{Copyrights}

Copyright for this article is retained by the author(s), with first publication rights granted to the journal.

This is an open-access article distributed under the terms and conditions of the Creative Commons Attribution license (http://creativecommons.org/licenses/by/4.0/). 